\title{
Omitted-variable bias in demand-regime estimations: the role of household credit and wage inequality in Brazil
}

Keywords: demand regimes, functional distribution of income, Brazilian inclusive growth, omitted-variable bias, distribution of wage

JEL codes: $E 12, E 25, D 33, C 32$

\section{INTRODUCTION}

The Kaleckian theoretical framework emphasizes the role of the functional distribution of income in determining the level of economic activity. In a closed economy, a country's demand regime is defined as wage-led when an increase in the wage share stimulates consumption more than it reduces investment, and as profit-led otherwise (Bhaduri and Marglin 1990; Dutt 1992; Marglin and Bhaduri 1990; Rowthorn 1981; Taylor 1985). These models have inspired numerous empirical studies that aimed at investigating how changes in the functional distribution of income affect a country's macroeconomic performance. Two different methods have been used for that purpose: individual equations, in which one separately estimates the impact of the distributive variable on each component of aggregate demand, and the vector autoregressive (VAR) method, which considers the two variables as endogenous and provides an overall estimation of their reciprocal relationship.

Although this vast existing empirical literature may be useful to clarify the relationship between demand and distribution in different economies and time periods, it faces numerous critiques. First, results tend to be inconclusive and sensitive to small 
methodological changes. VAR estimations suggest a dominance of profit-led regimes (Barbosa-Filho and Taylor 2006; Naastepad and Storm 2006). Studies that separately estimate the response of each demand component often find domestic demand as wage-led, but overall demand as profit-led due to price substitution effects on net exports, especially in the case of small open economies (Bowles and Boyer 1995; Hein and Vogel 2008; Naastepad and Storm 2006; Onaran and Galanis 2012; Stockhammer and Onaran 2004). However, despite these general findings, different studies carried out for the same country and time period often give rise to conflicting results.

Many factors highlighted by the literature may help to explain the variety and fragility of results: omitted variables (Stockhammer 2017), different time horizons in the response of demand components (Blecker 2015), endogeneity of income distribution (Skott 2015), structural breaks and possible non-linearities (Mendieta-Munoz et al. 2020; Nikiforos and Foley 2012; Palley 2014), and the need to consider other markets in addition to the goods markets in the analysis (Mendieta-Munoz et al. 2020; Schoder 2017). In this context, this study aims to analyse the relationship between income distribution and aggregate demand in Brazil from 1995 to 2014. Our goal is not to determine its demand regime but rather to identify how additional variables that seem relevant for the Brazilian growth experience of the 2000s affect the estimations of a standard VAR model for capacity utilization and the wage share. In other words, our econometric strategy will try to address a possible omitted-variable bias in the estimations by including exogenous control variables in a two-dimensional VAR.

The motivation for the study of the Brazilian case is in the apparent contradiction between various econometric estimations that established the country's demand regime as profit-led (Araujo and Gala 2012; Jesus et al. 2018) and the combination of higher GDP growth and higher wage share experienced in the early twenty-first century. In particular, by observing the positive association between aggregate demand and real wages, some have treated the period as one of wage-led growth even if econometric results pointed in the opposite direction (Serrano and Summa 2012b). But when the Brazilian economy started to slow down in 2011, others have attributed the failure to sustain higher rates of economic growth precisely to the rise in the wage share (Bresser-Pereira 2012; Oreiro et al. 2012). In other words, what they considered to be a profit-led economy would end up eventually being harmed by the continuous reduction in the profit share. By considering other variables that could help explain the observed trajectory of growth and distribution in Brazil in the twenty-first century, our study questions both these interpretations and, more generally, the importance of the demand regime itself to explain the acceleration and the subsequent slowdown of the Brazilian economy during this period.

Section 2 addresses the relationship between effective demand and the functional distribution of income by briefly examining the theoretical and empirical literature on Kaleckian models and some of the critiques to the empirical estimations of demand regimes. In Section 3, we analyse the experience of inclusive growth in the Brazilian economy in the 2000s in order to come up with economic variables that could have altered the relationship between economic activity and income distribution in the period. The econometric results of our empirical exercise that controls for such variables will be presented and analysed in Section 4 . Section 5 concludes the paper.

\section{KALECKIAN MODELS AND DEMAND-REGIME ESTIMATIONS}

The Neo-Kaleckian model seminally developed by Amadeo (1986), Bhaduri and Marglin (1990), Rowthorn (1981), and Taylor (1985) analyses how the functional 
distribution of income affects effective demand in a two-class economy with excess capacity. Lavoie (2014) argues that four aspects undoubtedly classify a growth and distribution model as Kaleckian: (i) the investment function depends on the degree of capacity utilization; (ii) prices are set as a mark-up over unit labor costs; (iii) the marginal propensity to consume out of profits is lower than the marginal propensity to consume out of wages; and (iv) the degree of capacity utilization is below unity, so that the economy operates with idle capacity, and labor supply is not a binding constraint.

In addition to the positive effect of capacity utilization, the investment function in Kaleckian models may also include the profit rate, such as in the so-called KaleckiSteindl specifications in Dutt (1984), Rowthorn (1981), and Taylor (1985), or the profit share, such as in the Post-Kaleckian version of Bhaduri and Marglin (1990). In such cases, a change in the functional distribution of income may have an ambiguous effect on aggregate demand. On the one hand, a redistribution towards profits has a negative impact on consumption due to capitalists' higher propensity to save. On the other, it may have a negative impact on investment through lower profit margins. If the rise in investment more than offsets the fall in consumption, the economy is said to be profit-led. If a reduction in the profit share boosts consumption more than it harms investment, the demand regime is wage-led.

Based on this framework, the literature has followed different paths. Many theoretical developments have focused on extending the canonical model to include other variables that may affect the impact of income distribution on demand. Blecker (2011), Lavoie and Stockhammer (2013), and Rezai (2011) have dealt with the effect of changes in distribution on net exports due to the role of unit labor costs for each country's competitiveness and of the level of economic activity for the volume of imports. Carvalho and Rezai (2015), Dutt (1992), Lavoie (1996), and Tavani and Vasudevan (2014) have extended the standard model to include an additional managerial or hybrid class to that of capitalists and workers or to incorporate wage disparities between workers to the relationship between growth and distribution. Dutt (2006) and Palley (2010) have addressed the short- and long-run effects of introducing household debt into the model.

Other extensions have focused on modeling the other direction of causality, namely the impact of aggregate demand on distribution, by introducing conflict inflation and Goodwin cycles (Goodwin 1967) such as in Hein (2007) and Taylor (2004), and/or by focusing on Kaldor-Verdoorn effects and other endogenous responses of labor productivity (Naastepad 2006; Storm and Naastepad 2013). To consider the effect of aggregate demand on income distribution, Taylor (2004) adds a distributive curve to the standard model. A demand-driven economy with Goodwin-type features combines a profit-led demand regime (a negatively sloped effective demand curve in the wage share-capacity utilization space) and a profit-squeeze distributive regime (positively sloped distributive curve in the wage-share-capacity-utilization space). For a profit squeeze to occur, workers' bargaining power and hence real wages need to respond more than labor productivity to an economic expansion.

\subsection{Demand-regime estimations}

In the empirical area, numerous studies have attempted to determine countries' demand regime as either wage-led or profit-led in different periods of time. These developments used two different empirical strategies. In so-called structural estimations, the idea is to estimate the impact of changes in the functional distribution of income on each component of aggregate demand - consumption, investment, exports, and imports - by running individual equations (Bowles and Boyer 1995; 
Naastepad and Storm 2006; Onaran and Galanis 2012; Stockhammer and Ederer 2008; Stockhammer et al. 2009). This method aims at capturing the overall response of aggregate demand to shifts in the functional distribution of income from the estimated coefficients for each component, thus allowing us to distinguish open-economy and domestic-demand effects.

A country's demand regime is then defined by adding up the distribution coefficient in each equation divided by the Keynesian multiplier, as in the theoretical version of the model. Algebraically one starts from the following equation:

$$
A D=C(Y, \psi)+I(Y, \psi, z I)+N X(Y, \psi, z N X)+G(Y, z G),
$$

where $\psi$ is the wage share and $z$ represents exogenous variables in each demand component equation. They assume goods market clearance, that is, output equals aggregate demand $\left(Y^{*}=A D\right)$. To determine the demand regime, we differentiate $Y^{*}$ with respect to $\psi$ and rearrange terms, so as to get:

$$
\frac{d Y^{*}}{d \psi}=\frac{H_{2}}{1-H_{1}}
$$

where $H_{1}=\left(\frac{\partial C}{\partial y}+\frac{\partial I}{\partial y}+\frac{\partial N X}{\partial y}+\frac{\partial G}{\partial y}\right)$ and $H_{2}=\frac{\partial C}{\partial \psi}+\frac{\partial I}{\partial \psi}+\frac{\partial N X}{\partial \psi}$.

The term $1 /\left(1-H_{1}\right)$ is a standard multiplier and should be positive to guarantee the model's stability. The sign of the derivative depends, therefore, on the numerator, which is determined econometrically by estimating individual equations for consumption, investment, and net exports one by one. If $H_{2}>0$, and therefore $\partial Y^{*} / \partial \psi>0$, the demand regime is wage-led; otherwise it is profit-led overall.

In studies using the so-called aggregate approach, the overall relationship between the functional distribution of income and the degree of capacity utilization is estimated through a two-dimensional VAR (Barbosa-Filho and Taylor 2006; Naastepad and Storm 2006). In this case, a dynamic and simultaneous equations system such as the one that follows is estimated:

$$
\begin{aligned}
& \dot{u}=g(u, \psi)=u\left(\psi_{0}+\psi_{u} u+\psi_{\psi} \psi\right) \\
& \dot{\psi}=h(u, \psi)=\psi\left(\theta_{0}+\theta_{u} u+\theta_{\psi} \psi\right),
\end{aligned}
$$

where dynamics are analysed around the steady state $\dot{u}=\dot{\psi}=0$.

The method deals appropriately with the reciprocal endogenous relationship between distribution and demand, thus overcoming the first method's implicit assumption that income distribution is exogenously determined. Its analysis requires a more careful interpretation, since it is not possible to precisely detect the channels through which distribution affects economic activity, nor to distinguish between the open- and the closed-economy effects (Onaran and Galanis 2012).

Studies that estimate the response of each demand component separately (Bowles and Boyer 1995; Hein and Vogel 2008; Naastepad and Storm 2006; Onaran and Galanis 2012; Onaran and Obst 2016; Stockhammer and Ederer 2008; Stockhammer et al. 2009) often find domestic demand as wage-led, but total demand - as including the effect of distribution on net exports - as profit-led. This seems particularly true for small open economies, where international trade represents a large share in countries' total demand, as pointed out by Hein and Vogel (2008). When analysing the demand regime for five European countries and the USA from 1960 to 2005, the study finds 
wage-led regimes for France, Germany, the USA, and the UK, and profit-led regimes for the two smaller economies included in the sample, Austria and the Netherlands. In the Austrian case, removing the effect on net exports switches the demand regime to wage-led - that is, the country is considered wage-led domestically. Therefore, the higher the country's dependency to the international market and the more sensitive it is to shifts in international prices, the more it will tend to be profit-led or weakly wage-led when open-economy effects are considered.

Studies using the aggregate method have mostly focused on advanced economies and found predominantly profit-led responses (Barbosa-Filho and Taylor 2006; Basu and Gautham 2019; Diallo et al. 2011; Franke et al. 2006; Kiefer and Rada 2015), although recent studies with extended models raise questions about the robustness of previous results (Cauvel 2019).

For the American economy specifically, in Barbosa-Filho and Taylor (2006), a long-run analysis suggests a profit-led demand curve and a profit squeeze distributive curve, that is, positive shocks to the wage share lead to a reduction in the degree of capacity utilization while positive demand shocks increase the wage share. These results for the demand regime are also found in Basu and Gautham (2019), who extend the basic VAR model with additional variables (the accumulation rate, the unemployment rate, and the growth rate of labor productivity). The same results for the distributive cycle appear in Barrales-Ruiz et al. (2020). However, by correcting for cyclical effects of demand on productivity, Cauvel (2019) finds a wage-led demand regime and no significant effects of demand on distribution in the US.

In the Brazilian case, empirical investigations of demand regimes have followed different strategies and offered ambiguous results, as synthesized in Table 1. Araújo and Gala (2012) estimate individual equations for the response of the different components of aggregate demand to the functional distribution of income by using quarterly data from 2002 to 2008 . They find that while domestic demand is wage-led, the inclusion of the foreign sector turns the demand regime profit-led overall, suggesting that the Brazilian economy responded positively to the profit share in the analysed period. The same results can be found in Feijó et al. (2015b) for a previous period (19511989). The authors use the aggregate method of Hein and Vogel (2008) and identify a profit-led regime for the Brazillian economy in the period.

Bruno (2005), in turn, finds two patterns of accumulation: a profit-led regime in the 1970-1990 period and a wage-led regime in 1991-2001, with the latter being characterized by 'growing financialization' and a rise in unproductive investment.

Tomio (2016) also estimates Brazil's demand regime through individual equations for the different components of aggregate demand but finds wage-led results for the longer period 1956-2008 by using annual data. The author argues that the difference between Bruno (2005) and Araújo and Gala's (2012) results can be attributed to two factors: the lack of significance of the profit share in the estimation of the investment function, also present in the other studies, and the negative estimated effect of the profit share on net exports, as opposed to the other studies.

Jesus et al. (2018), on the other hand, follow the aggregate method. They test empirically the basic Post-Kaleckian growth model by estimating a three-dimensional VAR with the GDP growth rate, capacity utilization, and the profit share with annual data from 1970 to 2008. Their analysis of impulse-response functions suggests that both the growth and the demand regimes of the Brazilian economy are profit-led during the period.

Feijó et al. (2015a) investigate the relationship between capital accumulation, income distribution, and the debt ratio in a Kaleckian-Minskyan framework. They also follow 
Omitted-variable bias in demand-regime estimations: credit and inequality in Brazil

Table 1 Demand-regime estimations for Brazil

\begin{tabular}{|c|c|c|c|}
\hline Study & Period & Method & Result \\
\hline Araujo and Gala (2012) & 2002-2008 (quarterly) & Structural estimations & Profit-led \\
\hline Bruno (2005) & 1970-2001 (annual) & Structural estimations & $\begin{array}{l}\text { 1970-1990: Profit-led } \\
\text { 1991-2001: Wage-led }\end{array}$ \\
\hline $\begin{array}{l}\text { Feijó et al. (2015a) } \\
\text { (Kaleckian-Minskyan } \\
\text { framework) }\end{array}$ & 1995-2009 (quarterly) & Aggregate method & Wage-led \\
\hline Feijó et al. (2015b) & 1951-1989 (annual) & Structural estimations & Profit-led \\
\hline Jesus et al. (2018) & 1970-2008 (annual) & Aggregate method & Profit-led \\
\hline Tomio (2016) & 1956-2008 (annual) & Structural estimations & Wage-led \\
\hline
\end{tabular}

Source: Authors.

the aggregate method by estimating a VAR, but they use quarterly data from 1995 to 2009. Their analysis of accumulated impulse-response functions finds a wage-led growth pattern as well as a debt-burdened pattern for capital accumulation. The inclusion of a third endogenous variable, the debt series in this case, seems to have altered the relationship between capital accumulation and the functional distribution of income found in Jesus et al. (2018).

The ambiguity of results goes in line with Marrone's (2015) findings, namely that the functional distribution of income in Brazil does not Granger-cause capital accumulation (1950-2008), thus suggesting that growth and demand can increase either with a concentration or deconcentration of income.

\subsection{The critique}

Empirical investigations of demand regimes are often criticized theoretically and methodologically. Blecker (2015) is concerned with the variety of results arising from the two different econometric methods at times for the same country. The author emphasizes the importance of identifying the correct econometric and theoretical specification and to consider all the relevant control variables in order to find more robust and solid results. He also argues that structural changes are inherent to economic dynamics and may not be captured by models that assume constant parameters over time, that is, the existence of structural breaks or non-linear regimes would incur in time-varying parameters.

Skott (2015) argues that the hypothesis of exogenous distribution weakens results of structural estimations. He even questions the 'demand regime' terminology, for it implies a one-way direction of causality between the two variables. Distribution is also subject to the economy's performance, to institutional arrangements, and to the distributive conflict, as discussed in the Kalecki-Goodwin literature (Goodwin 1967).

In another criticism of the strategy based on individual equations, Schoder (2017) questions the idea of adding up coefficients for each demand component obtained at different significance levels. The method is empirically unusual and the results that emerge from them cannot be considered statistically significant.

The VAR method, on the other hand, estimates simultaneously the relationship between demand and distribution, thus dropping the exogeneity assumption and the need to add up point coefficients to determine the demand regime. However, results seem to be very sensitive to the number of lags used for the dependent 
variables and to the ordering and type of impulse-response functions (Schoder 2017). Onaran and Galanis (2012) also argues that the interpretation of VAR estimations is sinuous, for it does not allow us to distinguish between the open- and closed-economy effects.

Palley (2014) goes further by questioning the sole existence of stable demand regimes. He argues that the demand regime is not exogenous to its context, nor a natural and unique tendency of each economy. The characterization of economies as profit- or wage-led would be temporary, subject to the operating macroeconomic policies. The non-linearity and non-stability of demand regimes is also questioned by Nikiforos (2014), who rightly points out that a wage-led economy would hardly find its best possible performance with the total income being distributed to wages, as implied by the theoretical model. Blecker (2015) adds that it is necessary to consider the temporal horizon of the analysis (distinction of short- and long-term responses of different demand components to changes in distribution). He concludes that for this and other reasons listed above, empirical research in the area should adapt structural models to dynamic systems that consider other spheres of the economy beyond aggregate demand and to simulations which could potentially capture ignored interactions in the ordinary least squares (OLS) estimation.

In the policy area, as many have pointed out, the functional distribution of income is not subject to the direct control by the government, even if it can be indirectly affected by other policy variables. As also suggested by Skott (2015) based on the Lucas critique, it is more suitable for policy purposes to rely on estimations of how changes in the minimum wage, in the exchange rate, in government transfers, in labor institutions, or in the tax structure, that is, of policy variables, affect distribution and growth. He also argues that, by taking into account other markets, such as labor markets, the conclusions of individual estimates that only consider the dynamics of aggregate demand should no longer be valid. The inclusion of equations for the labor market and for the supply side of the economy would more adequately characterize the relationship between distribution and demand, allowing for better policy implications.

Finally, Carvalho and Rezai (2015), Palley (2014), and Stockhammer (2017) highlight the omitted-variable bias problem, that is, the need to consider theoretical extensions that go beyond the open-economy effect in demand-regime estimations.

In Mendieta-Munoz et al. (2020), for instance, the wage share is found to be sensible to wage-bargaining shocks, while Stockhammer (2017) highlights that the omission of financial variables is a major shortcoming of the exiting empirical literature. Indeed, a strong significant effect of debt and property prices on consumption and investment of OECD countries is found in Stockhammer and Wildauer (2016). In Obst et al. (2017), the incorporation of taxes on capital and labor in a Post-Kaleckian open-economy model increases the likelihood of a wage-led demand regime, while the integration of public spending increases multiplier effects and amplifies the wage-led outcome. Therefore these studies stress the need to consider the role of labor market dynamics, debt, and other financial variables as well as that of government spending in the definition of demand regimes.

Carvalho and Rezai (2015) emphasize the need to consider changes in personal income inequality: by re-estimating the study of Barbosa-Filho and Taylor (2006) for the USA while adding a threshold variable to capture changes in the personal income distribution, they find that the US economy has turned more profit-led in the high-inequality period. This result is supported by the study of Rolim (2019), who finds that income redistribution away from workers and towards managers 
increases the likelihood of profit-led demand. Palley (2014) also argues that the increase in inequality in several European countries and the United States must have contributed to turn demand regimes more profit-led in empirical studies. These results are supported on theoretical grounds in Palley (2016), which shows that changes in the distribution of wages can change an economy's character. Not taking the personal distribution or other relevant extensions into account may be biasing current estimations.

\section{GROWTH AND DISTRIBUTION IN BRAZIL IN THE 2000s}

Similarly to other Latin American economies, Brazil was able to combine higher GDP growth rates with a higher wage share during the commodity-price boom of the 2000s. However, after the economy slowed down in 2011 and entered one of the deepest and longest economic crises in its history, many questioned the sustainability of its previous growth model. Focusing only on demand-led interpretations of the Brazilian growth trajectory in the twenty-first century, one can distinguish two main viewpoints. The first considers that the economy could have continued to grow in the same fashion if the government had maintained its expansionary fiscal and credit policies after 2011 (Serrano and Summa 2012a). The second focuses on the overappreciation of the real exchange rate and the consequent lack of competitiveness of Brazilian manufacturing as having prevented the wage-led strategy from being successful for a longer period (Bresser-Pereira 2012; Oreiro and Araujo 2013; Oreiro et al. 2012).

In this context, Carvalho and Rugitsky (2015) highlight three main aspects that could explain the growth acceleration with inequality reduction that took place in Brazil in the 2000s: a heated international market for the country's exports; income redistribution at the bottom, and the expansion in access to household credit. First, China's rapid growth has benefited the Brazilian economy, both directly and indirectly. Indeed Borges (2016) finds that between 38 percent and 54 percent of the variation in Brazil's GDP per capita during the period was due to external factors that affected other commodity-exporting economies. Santos et al. (2016) find that private investment in Brazil responds significantly to commodity prices.

Second, distributive policies and the expansion in public investment have contributed to the creation of jobs in services and construction sectors and the generation of substantial income gains at the bottom of the distribution (Brenck and Carvalho 2019). The expansion of the cash transfer program Bolsa Família - from 3.6 million recipients in 2004 to 12.8 million in 2010 - and the rise in real minimum wages of 5.9 percent per year during this period helped to increase the meagre share of national income accruing to the bottom 50 percent from 12.9 percent in 2004 to 14.3 percent in 2014. When it comes to the specific role of Bolsa Família, studies have shown that 50 percent of the program's total expenditures are destined to families at the bottom 15 percent of the distribution pyramid, while 90 percent of its value was allocated to the 45 percent at the bottom (Hoffmann 2013). Econometric estimates suggest that between 17 and 40 percent of the reduction in the Gini index during the period can be attributed to the program (Barros et al. 2010; Calixtre 2014; Hoffmann 2013).

As for real minimum wage gains, which started after inflation stabilization in 1995 but became faster after 2004, Komatsu (2013) and Komatsu and Menezes Filho (2016) show how it affected both the functional and the personal distribution of income in Brazil. It does so by raising the average wage in the economy, as well as by reducing 
the difference between wages at the bottom and at the middle of the distribution, as shown in Figure 1. In fact, the minimum wage in Brazil not only sets a floor in the formal labor market, but also works as a baseline for different types of social benefits (for example, unemployment insurance, pensions, and social protection), which amplifies its role for inequality reduction. Indeed, the reduction in wage inequality in Brazil during this period has been even more substantial than the increase in the wage share. Estimates suggest that 68 percent of the observed reduction in wage inequality for men between 2004 and 2011 was due to the rise in the minimum wage (Komatsu 2013).

One can analyse the effect of this type of redistribution by considering the role of wage inequality in an extended Kaleckian model such as the one in Carvalho and Rezai (2015). If workers at the bottom of the income distribution have a higher propensity to consume than those in the middle, a reduction in wage disparities can boost consumption even if the wage share is held constant. The rise in the wage share would add to this effect as in the standard model. Household consumption did indeed grow on average 5.1 percent per year in real terms in Brazil in the 2004-2011 period. Dos Santos (2013) also draws attention to the fast expansion in investment in the period. Gross fixed capital formation grew on average 8.7 percent per year in the same period in spite of the fall in the profit share. In the Kaleckian framework, such fast growth of investment could be attributed to the boom in economic activity: in addition to the expansion in household consumption, the rise in public investment and exports also contributed as autonomous drivers of aggregate demand.

Finally, credit also seems to have played a role in boosting consumption. The country experienced a substantial expansion in access to credit in the 2003-2009 period, essentially due to the financial inclusion of middle-income families (Serrano and Summa 2015). The creation of credito consignado in 2004 - a payroll loan deducted monthly and automatically from the borrower's bank account - has been the most significant institutional change in this area. Extensions of Neo-Kaleckian models that consider the effect of household credit and debt accumulation on consumption (Dutt 2006; Setterfield 2014) attribute an ambiguous role to these variables. While

Labor share of income (\% GDP) - - - Average / minimum wage (\%) - secondary axis

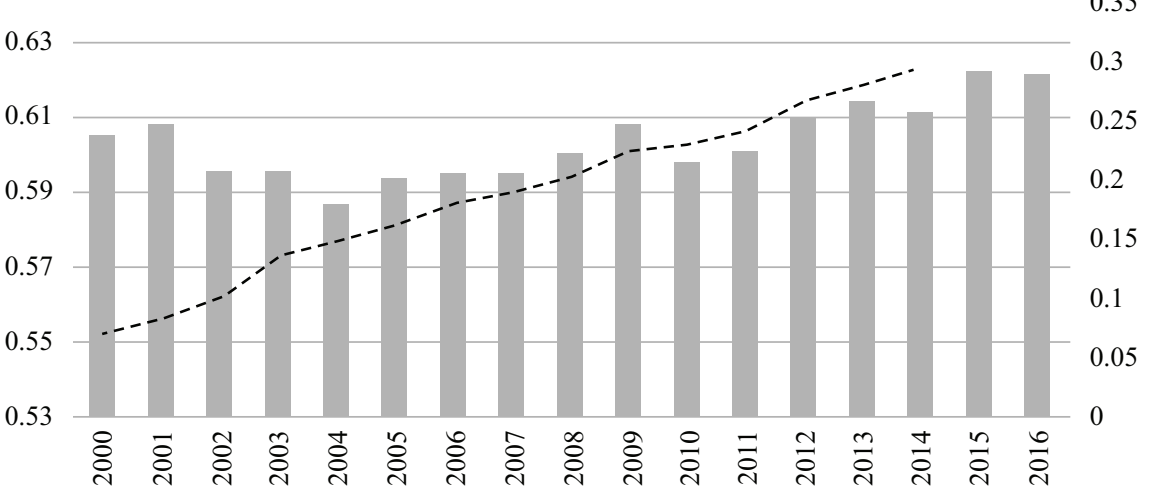

Source: PNAD-IBGE for the wage ration and SCN-IBGE for the wage share.

Figure 1 Evolution of wage share and wage ratios 
the short-term response of aggregate demand is positive through the boost in consumption, in the long run the effect may be ambiguous due to a redistribution from borrowers to lenders through interest payments. Schettini et al. (2012) find econometric evidence that aggregate consumption in Brazil has responded positively to the ratio of household credit to GDP in the short run.

Based on these different potential domestic and external drivers of demand-led growth in early twenty-first century Brazil, we will examine how selected variables may have played a role in altering the relationship between aggregate demand and distribution in the country.

\section{ECONOMETRIC ESTIMATIONS}

In particular, we aim to use the Brazilian economic experience in the 2000s to evaluate how empirical estimations of demand regimes may be neglecting important control variables. Our econometric exercise will start from a standard VAR estimation of the relationship between the functional distribution of income and the degree of capacity utilization, but will also control for exogenous variables that may have affected the relationship between demand and distribution in Brazil in the early twenty-first century.

We considered as potential candidates the variables discussed in the previous section that seemed to have an important role in the Brazilian experience, some of which had already been treated theoretically in extensions to the Kaleckian model. They are: (i) consumer credit; (ii) the Gini index for wages; (iii) commodity prices; and (iv) public investment, measured by government gross fixed capital formation (GFCF). Besides correcting for possible omitted-variable biases and to help in the interpretation of the Brazilian experience, the introduction of these control variables may help to highlight aspects that are not usually incorporated into the basic Kaleckian model but that could modify the relationship between aggregate demand and income distribution.

The inclusion of exogenous variables in VAR models is explained by Lutkepohl and Kratzig (2004) and take the following form:

$$
y_{t}=\Gamma_{1} y_{t-1}+\Gamma_{2} y_{t-2}+\ldots+\Gamma_{p-1} y_{t-p-1}+C D_{t}+B z_{t}+\epsilon_{t},
$$

where $z_{t}$ are the unmodeled stochastic variables, $D_{t}$ contains all regressors associated with deterministic terms, and $C$ and $B$ are parameter matrices. The exogenous variables in $z_{t}$ are not considered modeled because there is no explanatory equation for them in the system above. The inclusion of these variables can however compromise the model inference if exogeneity ${ }^{1}$ assumptions are not met. In this exercise we assured

1. There are three definitions of exogeneity according to Engle et al. (1983). A set of variables $z_{t}$ is said to be weakly exogenous to an array of parameters of interest, for example $y_{t}$ if $y_{t}$ 's estimation conditional to $z_{t}$ does not imply a loss of information when compared to the non-conditional estimation of $y_{t} . Z_{t}$ is said to be strongly exogenous if it is weakly exogenous on estimation but also on forecasts, that is, forecasts of $y_{t}$ conditional to $z_{t}$ will not improve its prediction in comparison to the non-conditional model estimation. Finally, superexogeneity happens when a variable is weakly exogenous, and if policy actions that affect the marginal process of the conditional model and forecasts of $y_{t}$ do not affect the parameters of the conditional process. Therefore, it can be said that weak exogeneity is important for inference, strong exogeneity for prediction, and superexogeneity for policy. 
exogeneity ${ }^{2}$ through Granger-causality ${ }^{3}$ tests, presented in Appendix 3. The test presented was performed with two lags, but tests with additional lags were performed for robustness and the results were maintained.

We estimated two-dimensional VARs for $y t=(u t, \psi t)$, where $u_{t}$ is the degree of capacity utilization and $\psi_{t}$ stands for the wage share. We then included exogenous variables $z_{i}$ one at a time. We also added time dummies for outliers, as in equations (6) and (7). Table 2 presents a description of the data series used in our exercise.

$$
\begin{gathered}
u_{t}=c_{u}+\sum_{n=1}^{4} \gamma_{1 n} u_{t-n}+\sum_{n=1}^{4} \delta_{1 n} \Psi_{t-n}+b_{i} z_{i}+c_{11} d 2009 q 1+c_{12} d 2001 q 4+\epsilon_{t 1} \\
\psi_{t}=c_{\psi} \sum_{n=1}^{4} \gamma_{2 n} u_{t-n}+\sum_{n=1}^{4} \delta_{2 n} \Psi_{t-n}+b_{i} z_{i}+c_{21} d 2009 q 1+c_{22} d 2001 q 4+\epsilon_{t 2}
\end{gathered}
$$

The baseline specification only includes the wage share, capacity utilization, and time dummies. We then estimated the model with each of the control variables and finally with all of them together. Due to problems of data availability, ${ }^{4}$ we decided to use quarterly data from 1997 to $2014^{5}$ (70 observations) in the exercise. The series used in the exercise are presented in Figure 2. The variable for capacity utilization was seasonally adjusted by the $x 12$ method. Unit-root tests suggested that our endogenous variables were stationary, ${ }^{6}$ that is, $\mathrm{I}(0)$, while all three exogenous variables were found

2. As noted by Geweke (1984), the concept of weak exogeneity by itself cannot generate a refutable hypothesis that can be subjected to statistical tests. The weak exogeneity assumption requires testing for concepts that are compatible with weak exogeneity and that can generate empirically refutable hypotheses. The strict exogeneity is such a concept, and in that case testing is possible, as discussed in Sims (1972).

3. The Granger-causality test is a statistical hypothesis test for determining whether one stochastic process is useful in forecasting another, or, in other words, if a variable is strongly exogenous to another. It checks for the significance of two variables' lags in each other through a $\mathrm{chi}^{2}$ (Wald test). As mentioned in footote 2, the Granger-causality test can be considered sufficient to assure weak and strong exogeneity, therefore assuring the necessary conditions for the econometric exercise.

4. Available data are insufficient for an econometric exercise at annual frequency. The series chosen for the control variables are only available from the 1990s (1992, in the case of the Gini, 1997 for commodity prices, and 1995 for public investment) to 2016.

5. Although the series are available until 2016, the inclusion of the last year of economic crisis compromised the stationary hypothesis of the two endogenous variables, as noted in footnote 6. Robustness tests performed with the entire series presented in the Appendices did not affect the results. The main results are presented with the reduced series in order to assure the basic assumptions of the VAR model.

6. Some ambiguity was identified for both endogenous variables. The degree of capacity utilization was found to be stationary in the Kwiatkowski-Phillips-Schmidt-Shin (KPSS) test (at 10 percent level), although found to be I(1) in the augmented Dickey-Fuller (ADF) test. The wage share was found to be integrated in the ADF test (at 1 percent level) and in the KPSS test, although only at the 10 percent level. Given the possibility of integrated series, we estimated an error correction model (ECM), which did not identify cointegration between the two series. We then tested for a reduced version of the sample (from 1997 to 2014), and found capacity utilization to be stationary in the KPSS ( 1 percent level) and in the ADF test (at 5 percent), while the wage share was found to be stationary in the KPSS test. In that way, we chose to follow the literature on demand-regime estimations and to carry out the analysis using the VAR method instead of an ECM using the reduced sample series, thus assuring comparability with previous literature. 


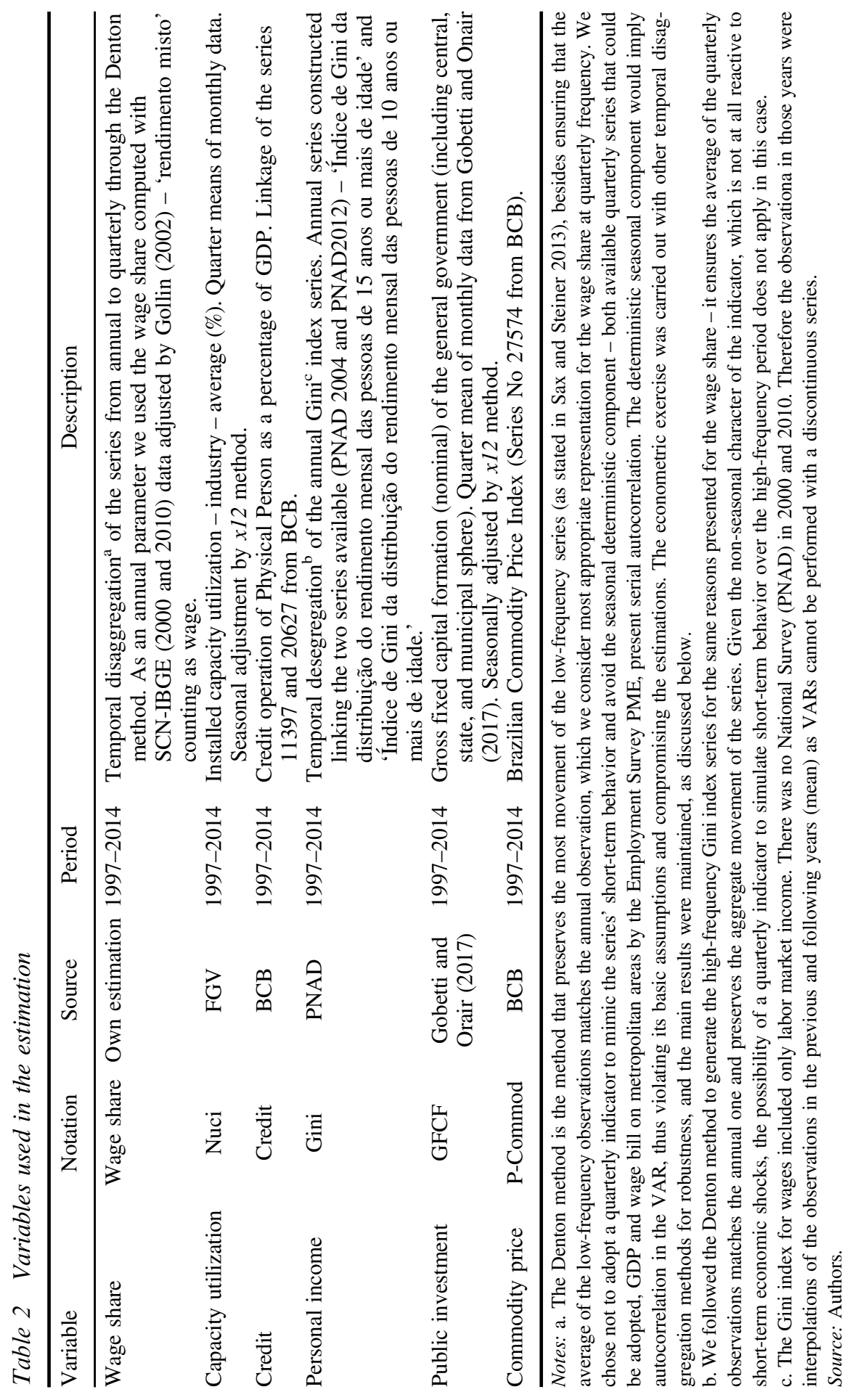



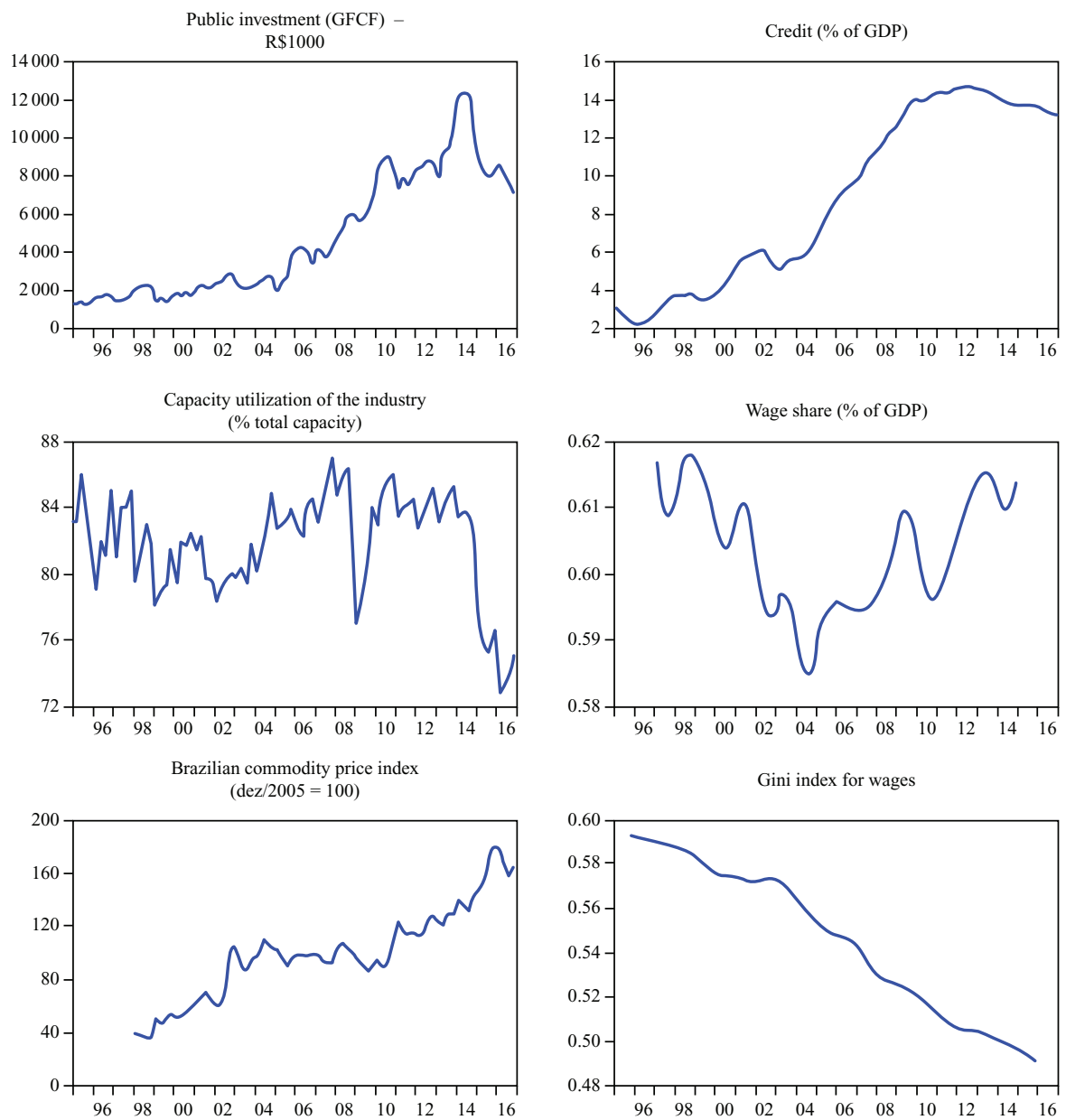

Source: Authors.

\section{Figure 2 Series used in the estimation}

to be integrated of order one, I(1). We present a table with the tests' coefficients in Appendix 2.

Our exogenous variables were thus considered in first difference in the model. We also introduced dummies for the first quarter of 2009 (financial crisis) and the fourth quarter of 2001 (Brazilian energy crisis). ${ }^{7}$ Hannan-Quinn and Schwarz tests for lag length suggested four lags in all specifications.

Given the recent debate concerning capacity utilization, it is worth mentioning a few methodological aspects about the Brazilian indicator and its capacity to capture the level of economic activity. Capacity utilization of the industry (known as NUCI,

7. Although the dummies were necessary to assure error normality tests in the VARs, estimations without the dummies were carried out for robustness. The results are maintained, as presented in Appendix 4. 
in Portuguese) is an indicator constructed by FGV / IBRE from monthly sample surveys of large, small, and medium-sized industrial companies, representative of the industrial universe, in 19 segments within four large sectors (consumer goods, capital, intermediate goods and construction material). The surveys are qualitative and aim to gather information about the economic dynamics, its tendency, perceptions, and expectations in relation to the economic moment. NUCI represents a reliable indicator for the output gap in the country, as pointed out by Borges (2020), because: (i) it illustrates with adherence the variations of physical production of the manufacturing industry and even those of a 'core' of GDP are not being affected by the NUCIs; (ii) it is able to adequately represent the various economic sectors, with both the simple average and the median being very similar to the aggregated NUCI indicator; and (iii) it is in fact one of the indicators with the greatest capacity to explain and anticipate the dynamics of inflation in Brazil.

Table A1 in Appendix 1 shows the estimated VAR coefficients. All exogenous variables were found to be significant in at least one of the estimated equations, except for commodity prices. In the case of the response of the degree of capacity utilization to changes in distribution, both credit and the Gini index were found to be significant at 10 percent, while public investment is significant at 5 percent despite the small magnitude of its coefficient. The equation for the wage share was also sensible to all three variables, but even more so to the Gini index and to public investment, which were found to be significant at 5 percent.

The effect of including different exogenous control variables - wage inequality, household credit, commodity prices, and public investment - on the estimated relationship between aggregate demand and distribution can be drawn from the impulseresponse functions. In all of them we followed a Cholesky ordering based on Kaleckian economic theory by ordering the wage share before capacity utilization in the decomposition. In other words, we assumed that economic activity responds faster to changes in distribution than the other way around.

As can be observed in the impulse-response functions presented in Figures 3 and 4 (overleaf), our baseline results suggest a profit-led demand regime and a positive response of the wage share to capacity utilization (profit-squeeze) in Brazil. These results are thus similar to those obtained by Barbosa-Filho and Taylor (2006) for the US economy and to the ones found by Jesus et al. (2018) for the Brazilian economy.

Figure 3 shows the accumulated responses of the wage share to a positive innovation shock in capacity utilization in each of our five VARs as well as in the baseline estimation that does not include any control variables (solid black line). The impulseresponse function illustrates the response of the wage share measured in percentage points given a Cholesky one standard deviation shock in capacity utilization, also measured in percentage points with dotted lines representing the 95 percent confidence intervals. Note that the profit-squeeze response of distribution was found significant in all specifications, suggesting a strong and solid reaction. Moreover, the response of the wage share to changes in capacity utilization was not found to be sensible to the inclusion of our control variables.

Figure 4 shows the accumulated response of capacity utilization to Cholesky one standard deviation ${ }^{8}$ shocks in the wage share, with dotted lines showing the 95 percent confidence interval of the response. Note that the profit-led result are only significant after approximately 20 periods, suggesting short- to medium-run interactions between

8. The Cholesky one standard deviation is 0.9 (percent) for capacity utilization and 0.086 (percent) for the wage share. 

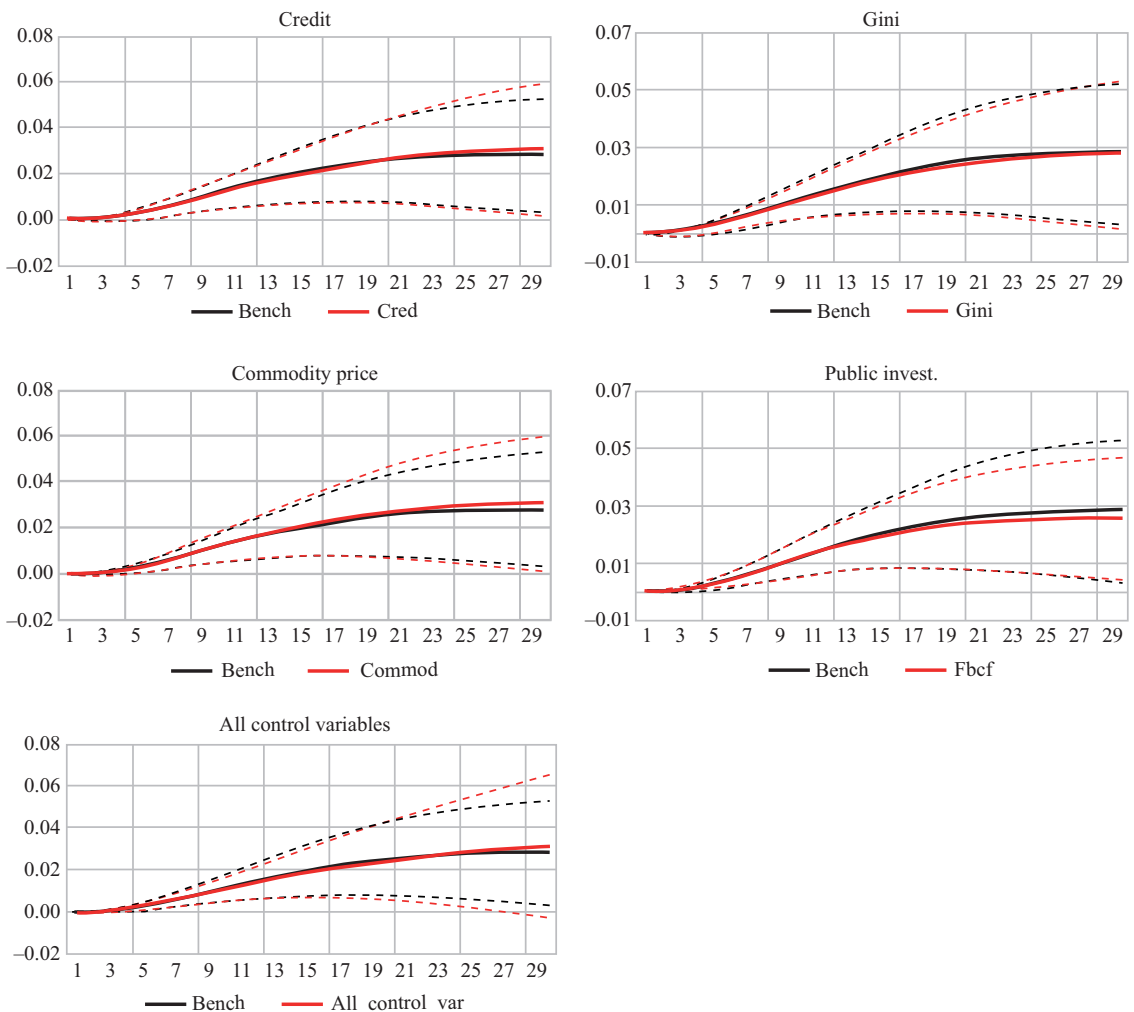

Note: Dotted lines show the 95 percent confidence interval or the impulse-response function. Source: Authors.

Figure 3 Wage-share accumulated response to innovation shocks on capacity utilization

capacity utilization and the wage share in Brazil in the period. In the benchmark estimation, a one standard deviation shock in the wage share results in approximately a 2.25 percentage points reduction in capacity utilization after five years with significance, as shown in Table 3.

Although we did not identify immediate significant effects in the first couple of years following the shock in the wage share, the analysis of the relationship between capacity utilization and distribution is still a short-run evaluation as it does not allow for the identification of permanent, long-run effects. The absence of strong short-run effects is puzzling and suggests that overall the evidence of profit-led demand in Brazil in the period is rather weak.

The inclusion of each of our four exogenous variables weakened the profit-led response of capacity utilization. The VAR that controls for commodity prices has shown the most similar response to the baseline after 20 periods (an effect of -2.3 versus -2.5 on the baseline), although not significant (the upper bound limit of the confidence interval was found to be positive) after 20 periods. The external factor captured by Brazilian main commodities prices was not found to be relevant to explain the estimated relationship between income distribution and demand during this period. 

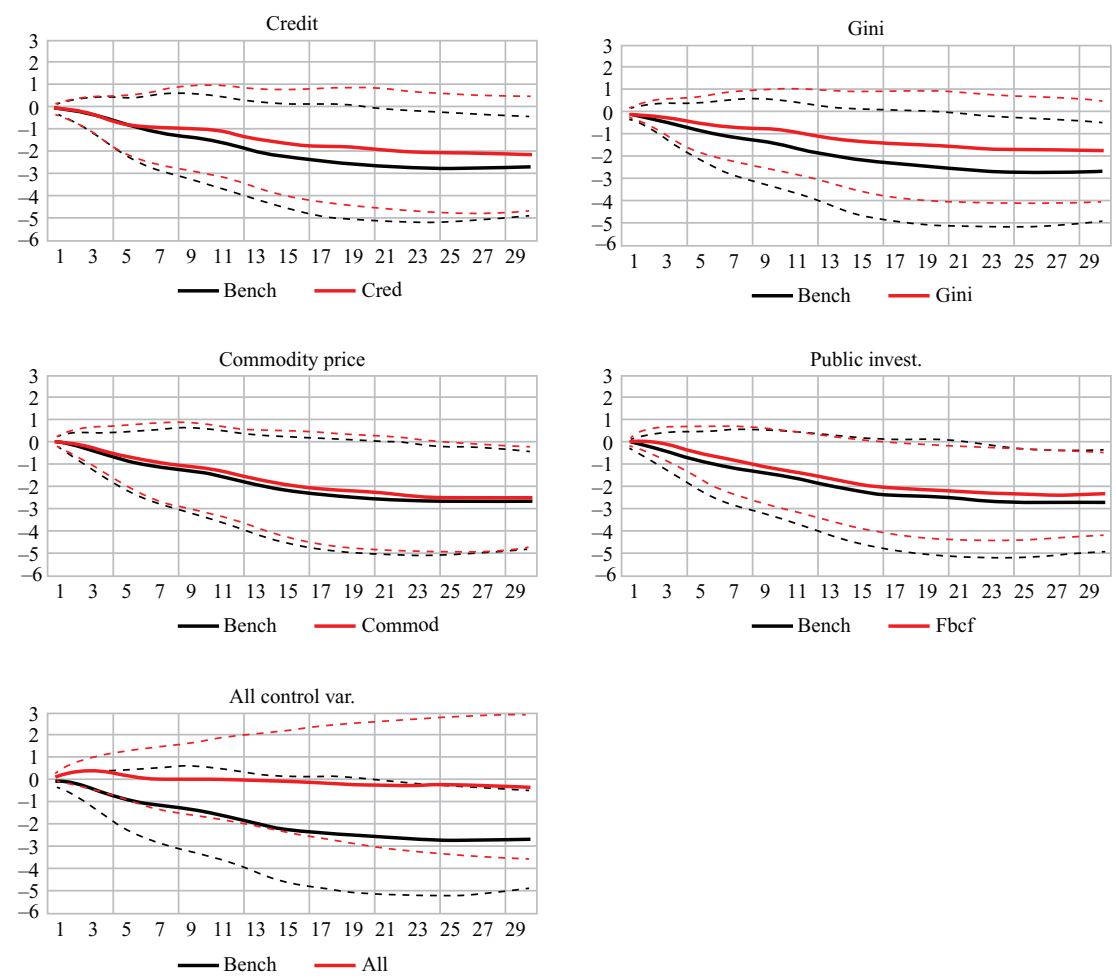

Note: Dotted lines show the 95 percent confidence interval or the impulse-response function. Source: Authors.

Figure 4 Capacity utilization accumulated response to innovations shocks on the wage share

Table 3 Accumulated response of capacity utilization to a standard deviation innovation shock on the wage share after 20 periods with confidence intervals

\begin{tabular}{lcccrrr}
\hline & Benchmark & Commodity prices & Public investment & Credit & Gini & All \\
\hline Upper bound & 0.0 & 0.3 & -0.1 & 0.9 & 0.9 & 2.6 \\
Effect & -2.5 & -2.3 & -2.2 & -1.8 & -1.5 & -0.2 \\
Lower bound & -5.0 & -4.8 & -4.3 & -4.5 & -3.9 & -2.9 \\
\hline
\end{tabular}

The inclusion of public investment as a control variable goes in the same direction as it also weakens the negative response of demand to the wage share, although the inclusion of this last control variable did not neutralize the profit-led character of the result as it was found to be significant after 20 periods.

The inclusion of the credit variable was more relevant and reduced even more the profit-led character of the estimated demand regime, lowering the effect of changes in the wage share on capacity utilization $(-1.8$ after 20 periods versus -2.5 in the baseline) and eliminating its significance throughout the whole period analysed. 
This suggests that part of the profit-led response of aggregate demand was due to the role of credit-driven consumption: the expansion of credit could have made household consumption less sensitive to changes in the wage share, thus reinforcing the estimated profit-led character of the economy in the baseline estimations.

Wage inequality was found to be the most relevant among our four control variables for the estimated demand regime, while wage disparities tilted the economy towards more 'profit-ledness.' This result had already been found in Carvalho and Rezai (2015) and Rolim (2019) for the US economy and is due to a higher propensity to consume of workers at the bottom of the distribution relative to those at the top, following Kaleckian literature. In other words, reducing the wage share seems to be less detrimental for aggregate demand when wages are highly concentrated at the top. Theoretically these results are demonstrated in Palley (2016), which finds that wage distribution can shift a country's regime character from profit- to wage-led.

The effect of one additional percentage point in the wage share was that of a reduction of 1.4 percentage points on capacity utilization after 20 periods (versus 2.5 in the baseline), but that effect is not significant as the upper bound of the confidence interval became positive.

Finally, when we control for all our four variables in the same VAR estimation, the profit-led result is the least after 20 periods (an effect of -0.17 of wage share on capacity utilization versus -2.5 on the benchmark analysis) loses all its statistical significance, as observed in most estimations.

The results can also be analysed through a variance decomposition evaluation, presented in Table 4 . The relevance of the wage share to explain capacity utilization's variance as from a shock is reduced on all controls, although in different magnitudes. As the impulse-response function analysis had already shown, the least relevant variable to alter the wage share's impact on demand was public investment, followed by commodity prices and credit. The wage distribution variables reduced in more than half the effect of the wage share on capacity utilization, highlighting once again the importance of the effect of wage distribution on capacity utilization, rather than distribution measured solely by the wage share.

Finally, estimations were performed with other specifications or data in order to guarantee robustness of the results. We tested the same exercise: ${ }^{9}$ (i) with annual variables, instead of quarterly, despite the restricted number of observations; (ii) without the outliers that were necessary to guarantee the normality hypothesis of the VAR; (iii) with the whole period available for the series, that is, 1997-2016, despite the absence of the stationary hypothesis for the endogenous variables in that case; (iv) with the whole sample period, with endogenous variables tested in differences; (v) with control variables treated as endogenous; and (vi) with different temporal disaggregation model for the wage share. An overview of the impulse-response functions is presented in Appendix 4; and Table 5 synthesizes these results.

The result of a weaker profit-led response when controlling for the chosen exogenous variables holds in all alternative specifications. The benchmark VAR, without any control variables, had the strongest profit-led response in all alternative specifications, with significance. The VAR specification controlling for all four exogenous variables

9. It is worth mentioning that while these exercises serve as a good instrument for robustness of the main results, they might face econometric issues (absence or normality, non-stationarity, restricted sample period) that could raise questions on the consistency of their results. Our chosen baseline econometric exercise remains, in our view, the most appropriate from a statistical standpoint. 
Table 4 Variance decomposition of wage share on capacity utilization

\begin{tabular}{crcccc}
\hline Period & Bench & Public invest. (GFCF) & Commodity prices & Credit & Gini index for wages \\
\hline 1 & $0.5 \%$ & $0.1 \%$ & $0.1 \%$ & $0.3 \%$ & $0.1 \%$ \\
2 & $0.5 \%$ & $0.1 \%$ & $0.1 \%$ & $0.3 \%$ & $0.0 \%$ \\
3 & $2.2 \%$ & $0.7 \%$ & $1.1 \%$ & $2.0 \%$ & $0.9 \%$ \\
4 & $4.3 \%$ & $2.1 \%$ & $2.6 \%$ & $4.0 \%$ & $2.1 \%$ \\
5 & $5.8 \%$ & $3.8 \%$ & $3.9 \%$ & $5.2 \%$ & $2.9 \%$ \\
6 & $6.6 \%$ & $5.1 \%$ & $4.6 \%$ & $5.5 \%$ & $3.2 \%$ \\
7 & $6.9 \%$ & $6.0 \%$ & $4.9 \%$ & $5.5 \%$ & $3.2 \%$ \\
8 & $7.1 \%$ & $6.7 \%$ & $5.1 \%$ & $5.5 \%$ & $3.2 \%$ \\
9 & $7.3 \%$ & $7.2 \%$ & $5.4 \%$ & $5.5 \%$ & $3.3 \%$ \\
10 & $7.7 \%$ & $7.8 \%$ & $5.7 \%$ & $5.5 \%$ & $3.4 \%$ \\
11 & $8.4 \%$ & $8.4 \%$ & $6.3 \%$ & $5.8 \%$ & $3.6 \%$ \\
12 & $9.2 \%$ & $9.1 \%$ & $7.1 \%$ & $6.4 \%$ & $4.1 \%$ \\
13 & $10.1 \%$ & $9.7 \%$ & $7.9 \%$ & $7.1 \%$ & $4.6 \%$ \\
14 & $10.8 \%$ & $10.3 \%$ & $8.5 \%$ & $7.7 \%$ & $5.0 \%$ \\
15 & $11.2 \%$ & $10.6 \%$ & $8.9 \%$ & $8.0 \%$ & $5.2 \%$ \\
\hline
\end{tabular}

Table 5 Effects in altering the significance of the profit-led demand regime in alternative econometric specification

\begin{tabular}{lccccc}
\hline Specification & $\begin{array}{c}\text { Public } \\
\text { investment }\end{array}$ & Gini & $\begin{array}{c}\text { Commodity } \\
\text { price }\end{array}$ & Credit & $\begin{array}{c}\text { All } \\
\text { controls }\end{array}$ \\
\hline Main econometric exercise & & $\mathrm{x}$ & $\mathrm{x}$ & $\mathrm{x}$ & $\mathrm{x}$ \\
Endogeneity of the control variables & $\mathrm{x}$ & & & $\mathrm{x}$ \\
No outliers & $\mathrm{x}$ & $\mathrm{x}$ & & $\mathrm{x}$ \\
Annual & $\mathrm{x}$ & & $\mathrm{x}$ & $\mathrm{x}$ \\
Alternative temporal disaggregation & $\mathrm{x}$ & & & $\mathrm{x}$ \\
Complete sample period & $\mathrm{x}$ & & & \\
Complete sample period with differenced & $\mathrm{x}$ & & & \\
$\quad$ series & & & & \\
\hline
\end{tabular}

still neutralized the profit-led character of the demand regime in five out of the six alternative results. ${ }^{10}$ This confirms the misconception in the recognition of the Brazilian demand as profit-led without the consideration of other factors that influence the relationship between the two variables.

The Gini index for wages was the only control variable capable of neutralizing the profit-led character of the demand regime in all alternative specifications. Hence our study confirms for the Brazilian economy previous findings by Carvalho and Rezai (2015) and Rolim (2019) that a reduction of inequality among workers causes the demand regime to be more wage-led in the US. Given how wage disparities have fallen in Brazil in the 2000s, these results point toward the role of this variable in explaining the economy's higher level of economic activity.

10. Although the profit-led character of the specification with the endogenous variables measured in differences was weakened and borders zero, the upper confidence interval band did not turn positive, as it did in the other estimations. 
The commodity-price variable was the one that least changed the relationship between demand and functional income distribution in all five robustness tests, suggesting it was not a relevant determinant for the relationship between distribution and demand, despite its recognized importance as an external driver of demand in the 2000s as discussed in Section 2. This is an interesting finding as part of the debate on the role of the commodity-price boom in explaining the Brazilian economic performance of the 2000s. Finally, the credit and public investment variables were not robust in weakening the profit-led character of the demand regime in all specifications, although significant effects of these two variables were still found in the exercise with the whole sample period such as in the baseline estimations.

In short, the econometric exercise performed in this paper highlighted how relevant factors for the performance of the Brazilian economy in the period have affected the relationship between aggregate demand and the functional distribution of income. Moreover, our analysis highlights the importance of extending Kaleckian models to account for other crucial variables that seem to affect the relationship between demand and distribution. Our results also point toward a potential omitted-variable bias in existing demand-regime estimations. Establishing the role of the wage share in explaining an observed process of demand-led growth based on such demand-regime estimations should be done more carefully, while policy prescriptions should probably be avoided altogether.

\section{CONCLUSION}

This article started from the Neo-Kaleckian theoretical framework and its extensions to analyse a possible omitted-variable bias in previous demand-regime estimations for Brazil. The country experienced an inclusive growth period in the 2000s in which the better macroeconomic performance was associated with a rise in the wage share. The apparent wage-led character of this economic boom conflicted with many econometric estimations that pointed towards a profit-led demand regime in Brazil. At the same time, other potential drivers of the country's higher GDP growth rates in the early twenty-first century have been identified in the literature: the commodity-price boom, the fast rise in public investment, the reduction in wage inequality, and the strong expansion of household credit. Our aim in this paper was to check whether these variables can change the relationship between capacity utilization and the wage share in a VAR model estimated for Brazil during this period.

For this purpose, we ran a two-dimensional VAR of the kind used to identify demand regimes in the standard empirical literature (Barbosa-Filho and Taylor 2006; Naastepad and Storm 2006), but which also included exogenous control variables for each of the four variables mentioned above, namely a commodity-price index, household credit, public investment, and a Gini index for wages. We then analysed whether the effect of changes in the functional distribution of income on the level of economic activity (and vice versa) varied across different specifications. Our results suggest that while the profit-squeeze type of response of distribution to changes in aggregate demand were not significantly affected by the inclusion of the four different control variables, the estimated profit-led character of the Brazilian demand regime lost its statistical significance when introducing these variables at the same time. Different exercises controlling for each of the four variables at a time also point toward a weaker profit-led response of capacity utilization. In particular, wage inequality plays a relevant role in neutralizing this effect, which makes sense if one draws on existing theoretical extensions to the Kaleckian model which imply that both variables could act to lower the 
sensitivity of consumption to a reduction in the wage share. In the case of wage inequality, the observed bias toward more profit-ledness in the standard estimations is in line with the findings in Carvalho and Rezai (2015) and Rolim (2019) for the US economy.

When it comes to the debate on the Brazilian economic growth process in the 2000s, the reduction of wage inequality and the expansion of household credit seem to have played a more important role in boosting household consumption and economic growth than the observed shifts in the functional distribution of income. In fact, one cannot even determine whether the rise in the wage share was good or bad for the country's macroeconomic performance during this period, not to say for the slowdown that came afterwards.

Besides helping in the interpretation of the drivers of the Brazilian inclusive growth and subsequent slowdown in the early twenty-first century, these results contribute in one dimension of recent criticisms to the existing empirical literature on demand regimes. The omission of crucial variables seems to play an important role in determining whether a country is found to be wage- or profit-led. One should take these estimations and associated policy prescriptions with a grain of salt.

\section{REFERENCES}

Amadeo, Edward J. (1986), 'The role of capacity utilization in long-period analysis,' Political Economy, 2(2), 147-185.

Araújo, Eliane and Paulo Gala (2012), 'Regimes de crescimento econômico no Brasil: evidências empíricas e implicações de política,' Estudos avançados, 26(75), 41-56.

Barbosa-Filho, Nelson H. and Lance Taylor (2006), 'Distributive and demand cycles in the US economy - a structuralist Goodwin model,' Metroeconomica, 57(3), 389-411.

Barrales-Ruiz, J., I. Mendieta-Munoz, C. Rada, D. Tavani, and R. von Arnim (2020), 'The distributive cycle: evidence and current debates,' Working Paper Series, Department of Economics, University of Utah (2020-07).

Barros, Ricardo, Mirela de Carvalho, Samuel Franco, and Rosane Mendonça (2010), 'Determinantes da queda na desigualdade de renda no Brasil,' Texto para discussão No 1460, IPEA.

Basu, D. and L. Gautham (2019), 'What is the impact of an exogenous shock to the wage share? VAR results for the US economy, 1973-2018,' Working Paper 2019-08, University of Massachusetts Amherst.

Bhaduri, Amit and Stephen Marglin (1990), 'Unemployment and the real wage: the economic basis for contesting political ideologies,' Cambridge Journal of Economics, 14(4), 375-393.

Blecker, Robert A. (2011), 'Open economy models of distribution and growth,' in Eckhard Hein and Engelbert Stockhammer (eds), A Modern Guide to Keynesian Macroeconomics and Economic Policies, Cheltenham, UK and Northampton, MA: Edward Elgar Publishing, pp. 215-239.

Blecker, Robert A. (2015), 'Wage-led versus profit-led demand regimes: the long and the short of it,' Paper Presented at the Eastern Economic Association, New York.

Borges, Bráulio (2016), 'Bad luck or bad policy: uma investigação das causas do baixo crescimento da economia brasileira nos últimos anos,' in Regis Bonelli and Fernando Veloso (eds), A Crise de Crescimento no Brasil, Rio de Janeiro: Elsevier/FGV-Ibre, pp. 19-39.

Borges, Bráulio (2020), 'Em Defesa do Nuci-FGV,' Blog do Ibre, FGV.

Bowles, Samuel and Robert Boyer (1995), 'Wages, aggregate demand, and employment in an open economy: an empirical investigation,' in Gerald A. Epstein and Herbert M. Gintis (eds), Macroeconomic Policy After the Conservative Era, Cambridge, UK Cambridge University Press, pp. 143-171.

Brenck, Clara and Laura Carvalho (2019), 'The equalizing spiral in early 21st century Brazil: a Kaleckian model with sectoral heterogeneity,' Technical Report, University of São Paulo (FEA-USP).

Bresser-Pereira, Luiz Carlos (2012), 'Structuralist macroeconomics and the new developmentalism,' Brazilian Journal of Political Economy, 32(3), 347-366. 
Bruno, Miguel (2005), Crescimento econômico, mudanças estruturais e distribuição: as transformações do regime de acumulação no Brasil, Doctoral Thesis, IE/UFRJ.

Calixtre, André Bojikian (2014), 'Nas fronteiras da desigualdade brasileira,' Report, Friedrich Ebert Stiftung Foundation.

Carvalho, Laura and Armon Rezai (2015), 'Personal income inequality and aggregate demand,' Cambridge Journal of Economics, 40(2), 491-505.

Carvalho, Laura and Fernando Rugitsky (2015), 'Growth and distribution in Brazil in the 21st century: revisiting the wage-led versus profit-led debate,' Technical Report, University of São Paulo (FEA-USP).

Cauvel, M. (2019), 'The Neo-Goodwinian model reconsidered,' PKES Working Paper 1915.

Diallo, Mamadou Bobo, Peter Flaschel, Hans-Martin Krolzig, and Christian R. Proano (2011), 'Reconsidering the dynamic interaction between real wages and macroeconomic activity,' Research in World Economy, 2(1), 77-93.

Dos Santos, C.H. (2013), 'Notas sobre as dinâmicas relacionadas do consumo das famílias, da formação bruta de capital fixo e das finanças públicas brasileiras no período 2004-2012,' in Vanessa Petrelli Correa (ed.), VP Padrão de acumulação e desenvolvimento brasileiro, São Paulo: Editora Fundação Perseu Abramo, pp. 182-242.

Dutt, Amitava Krishna (1984), 'Stagnation, income distribution and monopoly power,' Cambridge Journal of Economics, 8(1), 25-40.

Dutt, Amitava Krishna (1992), 'Unproductive sectors and economic growth: a theoretical analysis,' Review of Political Economy, 4(2), 178-202.

Dutt, Amitava Krishna (2006), 'Maturity, stagnation and consumer debt: a Steindlian approach,' Metroeconomica, 57(3), 339-364.

Engle, Robert F., David F. Hendry, and Jean-Francois Richard (1983), 'Exogeneity,' Econometrica, 51(2), 277-304.

Feijó, Carmem Aparecida, Marcos Tostes Lamonica, and Julio Cesar Albuquerque Bastos (2015a), 'Accumulation pattern of the Brazilian economy in the 1990s and 2000s,' International Review of Applied Economics, 29(1), 15-31.

Feijó, C.A., F.F. Câmara, and L.F Cerqueira (2015b), 'Inflation, growth, and distribution: the Brazilian economy after the post war,' Journal of Post Keynesian Economics, 38(4), 616-636.

Franke, Reiner, Peter Flaschel, and Christian R. Proano (2006), 'Wage-price dynamics and income distribution in a semi-structural Keynes-Goodwin model,' Structural Change and Economic Dynamics, 17(4), 452-465.

Geweke, J. (1984), 'Inference and causality in economic time series models,' Handbook of Econometrics, 2, 1101-1144.

Gobetti, Sérgio Wulff and Octávio Orair (2017), 'Resultado primário e contabilidade criativa: Reconstruindo as estatísticas fiscais' acima da linha' do governo geral,' Technical Report, 2288 IPEA.

Gollin, Douglas (2002), 'Getting income shares right,' Journal of Political Economy, 110(2), $458-474$.

Goodwin, Richard M. (1967), 'A growth cycle model,' in Carl Feinstein (ed.), Socialism, Capitalism, and Economic Growth, Cambridge, UK: Cambridge University Press, pp. 54-58.

Hein, Eckhard (2007), Money, Distribution Conflict and Capital Accumulation: Contributions to Monetary Analysis, New York: Springer.

Hein, Eckhard and Lena Vogel (2008), 'Distribution and growth reconsidered: empirical results for six OECD countries,' Cambridge Journal of Economics, 32(3), 479-511.

Hoffmann, Rodolfo (2013), 'Transferências de renda e desigualdade no Brasil,' Technical Report, IBGE.

Jesus, Cleiton Silva de, Ricardo Azevedo Araujo, and Carlos Eduardo Drumond (2018), 'An empirical test of the Post-Keynesian growth model applied to functional income distribution and the growth regime in Brazil,' International Review of Applied Economics, 32(4), 428-449.

Kiefer, David and Codrina Rada (2015), 'Profit maximising goes global: the race to the bottom,' Cambridge Journal of Economics, 39(5), 1333-1350.

Komatsu, Bruno Kawaoka (2013), Salário mínimo, desigualdade e informalidade, PhD Thesis, Universidade de São Paulo. 
Komatsu, Bruno and Naercio Menezes Filho (2016), 'Does the rise of the minimum wage explain the fall of wage inequality in Brazil?,' Working Paper, No 16, Insper.

Lavoie, Marc (1996), 'Unproductive outlays and capital accumulation with target-return pricing,' Review of Social Economy, 54(3), 303-322.

Lavoie, Marc (2014), Post-Keynesian Economics: New Foundations, Cheltenham, UK and Northampton, MA: Edward Elgar Publishing.

Lavoie, Marc and Engelbert Stockhammer (2013), 'Wage-led growth: concept, theories and policies,' in Marc Lavoie and Engelbert Stockhammer, Wage-Led Growth, London: Palgrave Macmillan, pp. 13-39.

Lutkepohl, Helmut and Markus Kratzig (2004), Applied Time Series Econometrics, Cambridge, UK: Cambridge University Press.

Marglin, Stephen. and Amit Bhaduri (1990), 'Profit squeeze and Keynesian theory,' in S.A. Marglin and J.B. Schor (eds), The Golden Age of Capitalism, Oxford: Oxford University Press, pp. 153-186.

Marrone, H. (2015), 'Do demand and profitability stimulate capital accumulation? An analysis for Brazil', Cepal Review, 116, 159-170.

Mendieta-Munoz, Ivan, Codrina Rada, Márcio Santetti, and Rudiger von Arnim (2020), 'The US labour share of income: what shocks matter?', Working Paper 2020-02, University of Utah, Department of Economics.

Naastepad, C.W.M. (2006), 'Technology, demand and distribution: a cumulative growth model with an application to the Dutch productivity growth slowdown,' Cambridge Journal of Economics, 30(3), 403-434.

Naastepad, C.W.M. and Servaas Storm (2006), 'OECD demand regimes (1960-2000),' Journal of Post Keynesian Economics, 29(2), 211-246.

Nikiforos, Michalis (2014), 'Distribution-led growth in the long run,' Levy Economics Institute, Working Papers Series 814.

Nikiforos, Michalis and Duncan K. Foley (2012), 'Distribution and capacity utilization: conceptual issues and empirical evidence,' Metroeconomica, 63(1), 200-229.

Obst, Thomas, Özlem Onaran, and Maria Nikolaidi (2017), 'The effect of income distribution and fiscal policy on growth, investment, and budget balance: the case of Europe,' Working Paper GPERC 43, Greenwich Political Economy Research Centre.

Onaran, Özlem and Giorgos Galanis (2012), 'Is aggregate demand wage-led or profit-led: national and global effects,' ILO Conditions of Work and Employment Series No 40, Geneva: International Labour Office.

Onaran, Özlem and Thomas Obst (2016), 'Wage-led growth in the EU15 member-states: the effects of income distribution on growth, investment, trade balance and inflation,' Cambridge Journal of Economics, 40(6), 1517-1551.

Oreiro, J.L. and E. Araujo (2013), 'Exchange rate misalignment, capital accumulation and income distribution: theory and evidence from the case of Brazil,' Panoeconomicus, 60(3), 381-396.

Oreiro, José Luis, Lionello F. Punzo, and Eliane C. Araujo (2012), 'Macroeconomic constraints to growth of the Brazilian economy: diagnosis and some policy proposals,' Cambridge Journal of Economics, 36(4), 919-939.

Palley, Thomas I. (2010), 'Inside debt and economic growth: a neo-Kaleckian analysis,' in Mark Setterfield (ed.), Handbook of Alternative Theories of Economic Growth, Cheltenham, UK and Northampton, MA: Edward Elgar Publishing, ch. 14.

Palley, Thomas I. (2014), 'Rethinking wage vs. profit-led growth theory with implications for policy analysis,' Technical Report, IMK Working Paper.

Palley, Thomas I. (2016), 'Wage- vs. profit-led growth: the role of the distribution of wages in determining regime character,' Cambridge Journal of Economics, 41(1), 49-61.

Rezai, Armon (2011), 'The political economy implications of general equilibrium analysis in open economy macro models,' Department of Economics/NSSR Working Paper 11.

Rolim, L.N. (2019), 'Overhead labour and feedback effects between capacity utilization and income distribution: estimations for the USA economy,' International Review of Applied Economics, 33(6), 756-773. 
Rowthorn, Bob (1981), Demand, Real Wages and Economic Growth, London: North East London Polytechnic.

Santos, C.H.D., A.D.M. Modenesi, G. Squeff, L. Vasconcelos, M. Mora, T. Fernandes, and J. Braga (2016), 'Revisitando a dinâmica trimestral do investimento no Brasil: 1996-2012,' Brazilian Journal of Political Economy, 36(1), 190-213.

Sax, Christoph and Peter Steiner (2013), 'Temporal disaggregation of time series,' The R Journal, $5(2), 80-87$.

Schettini, Bernardo Patta, Cláudio Hamilton Matos dos Santos, Cláudio Roberto Amitrano, Gabriel Coelho Squeff, Márcio Bruno Ribeiro, Raphael Rocha Gouvêa, Rodrigo Octávio Orair, and Thiago Sevilhano Martinez (2012), 'New empirical evidence on the quarterly dynamics of Brazilian aggregate household consumption from 1995 to 2009,' Economia e Sociedade, 21(3), 607-641.

Schoder, Christian (2017), 'Estimating Keynesian models of business fluctuations using Bayesian Maximum Likelihood,' Review of Keynesian Economics, 5(4), 586-630.

Serrano, Franklin and Ricardo Summa (2012a), 'A desaceleração rudimentar da economia brasileira desde 2011,' OIKOS (Rio de Janeiro), 11(2), 166-202.

Serrano, Franklin and Ricardo Summa (2012b), 'Macroeconomic policy, growth and income distribution in the Brazilian Economy in the 2000s,' Investigación Económica, 71(282), 55-92.

Serrano, Franklin and Ricardo Summa (2015), 'Aggregate demand and the slowdown of Brazilian economic growth in 2011-2014,' Nova Economia, 25(SPE), 803-833.

Setterfield, Mark (2014), 'Rising income inequality, increased household indebtedness, and Post Keynesian macrodynamics,' Working Paper No 1403, New School for Social Research, Department of Economics.

Sims, C.A. (1972), 'Money, income, and causality,' The American Economic Review, 62(4), $540-552$.

Skott, Peter (2015), 'Notes on wage-led versus profit-led growth,' in Kazuhiro Kurose (ed.), Workshop on Analytical Political Economy, Sendai, Japan, Tohoku: Tohoku University, pp. 24-25.

Stockhammer, E. (2017), 'Wage-led versus profit-led demand: what have we learned? A Kaleckian-Minskyan view,' Review of Keynesian Economics, 5(1), 25-42.

Stockhammer, Engelbert and Stefan Ederer (2008), 'Demand effects of the falling wage share in Austria,' Empirica, 35(5), 481-502.

Stockhammer, Engelbert and Olzem Onaran (2004), 'Accumulation, distribution and employment: a structural VAR approach to a Kaleckian macro model,' Structural Change and Economic Dynamics, 15(4), 421-447.

Stockhammer, E. and R. Wildauer (2016), 'Debt-driven growth? Wealth, distribution and demand in OECD countries,' Cambridge Journal of Economics, 40(6), 1609-1634.

Stockhammer, Engelbert, Ozlem Onaran, and Stefan Ederer (2009), 'Functional income distribution and aggregate demand in the Euro area,' Cambridge Journal of Economics, 33(1), 139-159.

Storm, Servaas and C.W.M. Naastepad (2013), 'Wage-led or profit-led supply: wages, productivity and investment,' in Marc Lavoie and Engelbert Stockhammer (eds), Wage-Led Growth, London: Palgrave Macmillan, pp. 100-124.

Tavani, Daniele and Ramaa Vasudevan (2014), 'Capitalists, workers, and managers: wage inequality and effective demand,' Structural Change and Economic Dynamics, 30, 120-131.

Taylor, Lance (1985), 'A stagnationist model of economic growth,' Cambridge Journal of Economics, 9(4), 383-403.

Taylor, Lance (2004), Reconstructing Macroeconomics: Structuralist Proposals and Critiques of the Mainstream, Cambridge, MA: Harvard University Press.

Tomio, Bruno Thiago (2016), 'Understanding the Brazilian demand regime: a Kaleckian approach,' Technical Report, Working Paper, Institute for International Political Economy Berlin. 
Omitted-variable bias in demand-regime estimations: credit and inequality in Brazil 391

\section{APPENDIX 1 ESTIMATION COEFFICIENTS}

Table A1 VAR coefficients

\begin{tabular}{|c|c|c|c|c|}
\hline & \multicolumn{2}{|c|}{ VAR_bench } & \multicolumn{2}{|c|}{ VAR_cred } \\
\hline & Nuci & Wage_share & Nuci & Wage_share \\
\hline $\operatorname{Nuci}(-1)$ & $1.025459 * * *$ & $2.91 \mathrm{E}-05$ & $1.009011 * * *$ & $3.60 \mathrm{E}-05$ \\
\hline $\operatorname{Nuci}(-2)$ & $-0.268926^{*}$ & $0.000250 *$ & $-0.237248 *$ & $0.000237 *$ \\
\hline $\operatorname{Nuci}(-3)$ & 0.089561 & $-0.000218 *$ & 0.060219 & -0.000206 \\
\hline $\operatorname{Nuci}(-4)$ & 0.009148 & $0.000211 * *$ & 0.018105 & $0.000207 * *$ \\
\hline Wage_share $(-1)$ & -0.574049 & $2.004612 * * *$ & 7.483421 & $2.001246^{* * *}$ \\
\hline Wage_share $(-2)$ & -178.055800 & $-1.336284 * * *$ & -204.416800 & $-1.325274 * * *$ \\
\hline Wage_share $(-3)$ & 295.950500 & 0.074479 & 336.413200 & 0.057579 \\
\hline Wage_share $(-4)$ & $-143.254900 *$ & $0.237673 * *$ & $-157.519400 *$ & $0.243631 * *$ \\
\hline $\mathrm{c}$ & $27.639860 * * *$ & -0.010667 & $23.202610 * *$ & -0.008814 \\
\hline $\mathrm{d} 2001 \mathrm{q} 4$ & -1.086844 & -0.000611 & -1.165345 & -0.000578 \\
\hline \multirow{4}{*}{$\begin{array}{l}\text { d2009q1 } \\
\text { d_credito }\end{array}$} & $4.199682 * * *$ & 0.001003 & $4.407766 * * *$ & 0.001090 \\
\hline & & & $0.694900 *$ & -0.000290 \\
\hline & \multicolumn{2}{|c|}{ Var_gini } & \multicolumn{2}{|c|}{ VAR_commod_p } \\
\hline & Nuci & Wage_share & Nuci & Wage_share \\
\hline $\operatorname{Nuci}(-1)$ & $1.014435 * * *$ & $4.38 \mathrm{E}-05$ & $1.006013 * * *$ & $4.92 \mathrm{E}-05$ \\
\hline $\operatorname{Nuci}(-2)$ & $-0.270750 *$ & $0.000252 *$ & -0.217857 & 0.000215 \\
\hline $\operatorname{Nuci}(-3)$ & 0.078995 & -0.000204 & 0.033219 & -0.000189 \\
\hline $\operatorname{Nuci}(-4)$ & 0.024513 & $0.000191 * *$ & 0.034076 & $0.000214 * *$ \\
\hline Wage_share $(-1)$ & 30.765530 & $1.963012 * * *$ & -2.574910 & $1.995034 * * *$ \\
\hline Wage_share $(-2)$ & -231.042900 & $-1.265949 * * *$ & -146.352100 & $-1.331757 * * *$ \\
\hline Wage_share $(-3)$ & 328.595700 & 0.031146 & 235.864000 & 0.069253 \\
\hline Wage_share $(-4)$ & $-146.238400 *$ & $0.241634 * *$ & -111.376600 & $0.250316^{* *}$ \\
\hline $\mathrm{c}$ & $23.227800 * *$ & -0.004811 & $26.741640 * *$ & -0.013536 \\
\hline $\mathrm{d} 2001 \mathrm{q} 4$ & -0.894107 & -0.000867 & -1.084221 & -0.000532 \\
\hline $\mathrm{d} 2009 \mathrm{q} 1$ & $4.148934 * * *$ & 0.000936 & $4.297329 * * *$ & 0.001078 \\
\hline d_gini & $-181.503500^{*}$ & $0.240926 * *$ & & \\
\hline \multirow[t]{3}{*}{ d_p_commod } & & & -0.007210 & $2.81 \mathrm{E}-06$ \\
\hline & \multicolumn{2}{|c|}{ Var_gfcf } & \multicolumn{2}{|c|}{ Var_all } \\
\hline & Nuci & Wage_share & Nuci & Wage_share \\
\hline $\operatorname{Nuci}(-1)$ & $0.967686 * * *$ & $8.16 \mathrm{E}-05$ & $0.937002 * *$ & 0.000115 \\
\hline $\operatorname{Nuci}(-2)$ & -0.224340 & 0.000209 & -0.182840 & 0.000188 \\
\hline $\operatorname{Nuci}(-3)$ & 0.091734 & $-0.000220 *$ & 0.027718 & -0.000180 \\
\hline $\operatorname{Nuci}(-4)$ & 0.006496 & $0.000213 * *$ & 0.059463 & $0.000185 *$ \\
\hline Wage_share $(-1)$ & -150241 & $2.005455 * * *$ & 391895 & $1.949915 * * *$ \\
\hline Wage_share $(-2)$ & -144123 & $-1.367129 * * *$ & -171573 & $1.308155^{* * *}$ \\
\hline Wage_share $(-3)$ & 2040907 & 0.157982 & 1506371 & 0.159059 \\
\hline Wage_share(-4) & -861298 & $0.185745^{* *}$ & -266528 & $0.171187 *$ \\
\hline c & $29.730110 * * *$ & $-0.012568 *$ & $17.766210 *$ & -0.008120 \\
\hline $\mathrm{d} 2001 \mathrm{q} 4$ & -0.974180 & -0.000710 & -0.578150 & -0.001090 \\
\hline
\end{tabular}


392 Review of Keynesian Economics, Vol. 9 No. 3

Table Al (continued)

\begin{tabular}{lccccc}
\hline & \multicolumn{2}{c}{ VAR_bench } & & \multicolumn{2}{c}{ VAR_cred } \\
\cline { 2 - 3 } \cline { 5 - 6 } & Nuci & Wage_share & & Nuci & Wage_share \\
\hline d2009q1 & $4.053232 * * *$ & 0.000870 & & $4.091694 * * *$ & 0.000753 \\
d_cred & & & & 0.512992 & 0.000110 \\
d_p_commod & & & 0.005617 & $-3.70 \mathrm{E}-06$ \\
d_gini & & & $-212.050200 *$ & 0.290582 \\
d_gfcf & $0.000521 * *$ & $0.000000474 * *$ & & $0.000627 * * *$ & $0.000000548 * * *$ \\
\hline
\end{tabular}

Note: $*$ if the coefficient is significant at the 10 percent level; $* *$ if the coefficient is significant at the 5 percent level, and $* * *$ if the coefficient is significant at the 1 percent level.

\section{APPENDIX 2 UNIT-ROOT TESTS}

\section{Table A2 Unit-root test}

\begin{tabular}{|c|c|c|c|c|c|}
\hline \multirow[b]{2}{*}{ Null hypothesis } & \multirow[t]{2}{*}{ Period } & \multicolumn{2}{|c|}{ KPSS } & \multicolumn{2}{|l|}{$\mathrm{ADF}$} \\
\hline & & Series & stationary & Series has a u & it root \\
\hline Capacity utilization (NUCI) & 1997-2016 & 0.149 & $\mathrm{I}(0)$ & -2.232 & $\mathrm{I}(1)$ \\
\hline Wage share & 1997-2016 & $0.356 *$ & Weakly I(1) & -1.754 & $\mathrm{I}(1)$ \\
\hline Capacity utilization (NUCI) & 1997-2014 & 0.094 & $\mathrm{I}(0)$ & $-3.143 * *$ & $\mathrm{I}(0)$ \\
\hline Wage share & 1997-2014 & 0.249 & $\mathrm{I}(0)$ & -0.975 & $\mathrm{I}(1)$ \\
\hline Gini & $1997-2015$ & $1.250 * * *$ & $\mathrm{I}(1)$ & -2.343 & $\mathrm{I}(1)$ \\
\hline Cred & 1997-2016 & $1.133 * * *$ & $\mathrm{I}(1)$ & -1.341 & $\mathrm{I}(1)$ \\
\hline P_commod & 1998-2016 & $1.039 * * *$ & $\mathrm{I}(1)$ & -0.657 & $\mathrm{I}(1)$ \\
\hline FBCF_GG & 1997-2016 & $1.078 * * *$ & $\mathrm{I}(1)$ & -2.128 & $\mathrm{I}(1)$ \\
\hline D_Gini & 1997-2015 & 0.194 & $\mathrm{I}(0)$ & -1.769 & $\mathrm{I}(1)$ \\
\hline D_Cred & 1997-2016 & 0.230 & $\mathrm{I}(0)$ & $-3.490 * *$ & $\mathrm{I}(0)$ \\
\hline D_p_commod & 1998-2016 & 0.112 & $\mathrm{I}(0)$ & $-7.586 * * *$ & $\mathrm{I}(0)$ \\
\hline D_fbcf_gg & 1997-2016 & 0.104 & $\mathrm{I}(0)$ & $-6.998 * * *$ & $\mathrm{I}(0)$ \\
\hline
\end{tabular}

Note: $*$ if the null hypothesis of the test is rejected at the 10 percent level; ** if the null hypothesis of the test is rejected at the 5 percent level, and *** if the null hypothesis is rejected at the 1 percent level.

\section{APPENDIX 3 GRANGER-CAUSALITY TEST}

\section{Table A3 Granger-causality test}

\begin{tabular}{lcccccc}
\hline Probability & Nuci & Wage_share & Cred & Gini & P_Commod & gfcf \\
\hline Nuci & - & 0.2418 & 0.0553 & 0.0105 & 0.2417 & 0.5921 \\
Wage_share & 0.0022 & - & 0.1902 & 0.0927 & 0.0364 & 0.1268 \\
Cred & 0.5414 & 0.1411 & - & - & - & - \\
Gini & 0.4759 & 0.7381 & - & - & - & - \\
P_Commod & 0.9214 & 0.6216 & - & - & - & - \\
gfcf & 0.5455 & 0.9343 & - & - & - & - \\
\hline
\end{tabular}

Note: Null hypothesis: variable (column) does not Granger-cause variable (line). 


\section{APPENDIX 4 ALTERNATIVE ESTIMATIONS FOR ROBUSTNESS}
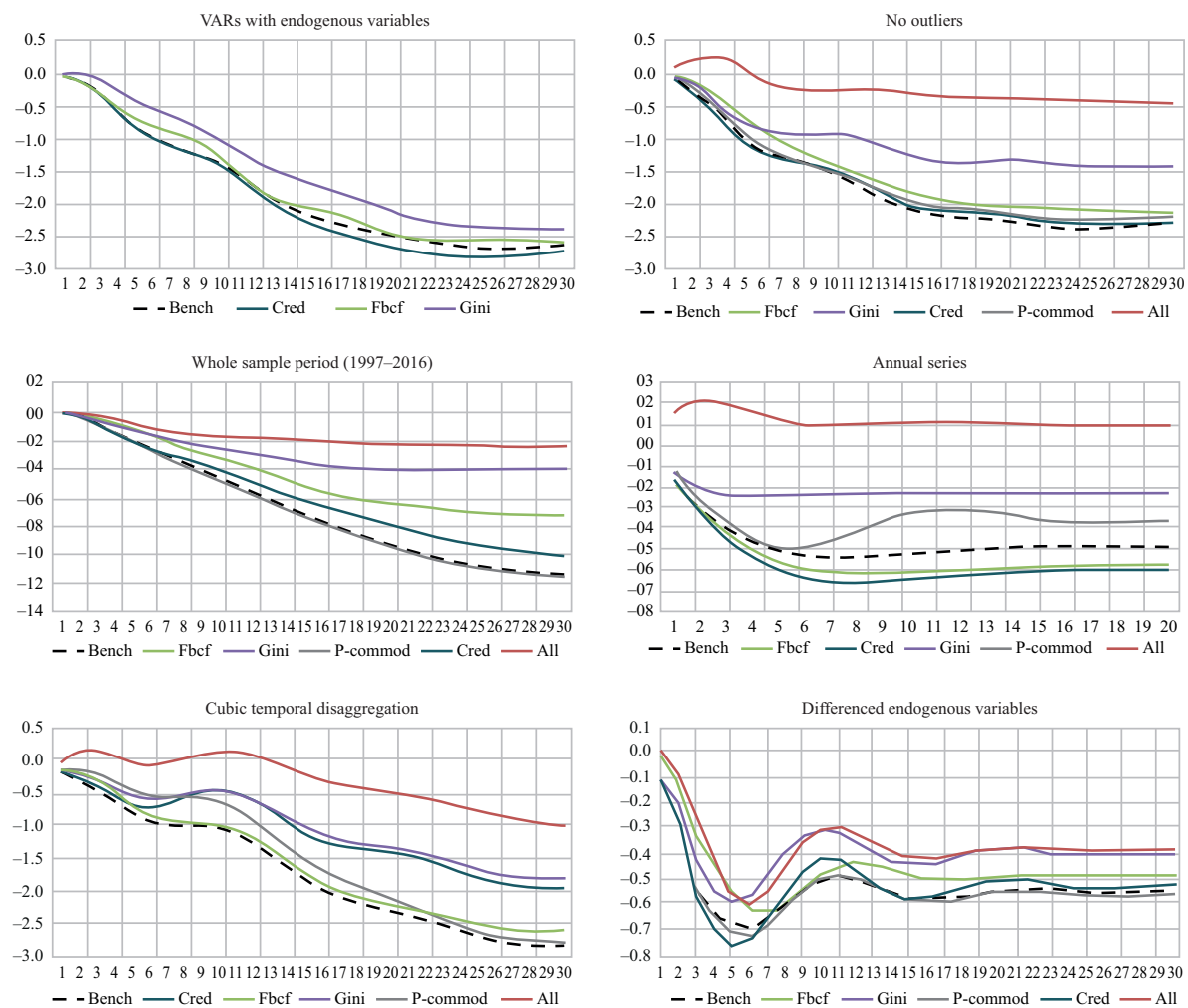

Figure Al Response of capacity utilization to shocks in the wage share in alternative estimations (for robustness) 